5-1-2015

\title{
"Liberat[ing] Mankind from such an Odious Scourge": The Genocide Convention and the Continued Failure to Prevent or Halt Genocide in the Twenty-First Century
}

Kelly Maddox

Lancaster University

Follow this and additional works at: https://digitalcommons.usf.edu/gsp

\section{Recommended Citation}

Maddox, Kelly (2015) "'Liberat[ing] Mankind from such an Odious Scourge": The Genocide Convention and the Continued Failure to Prevent or Halt Genocide in the Twenty-First Century," Genocide Studies and Prevention: An International Journal: Vol. 9: Iss. 1: 48-65.

DOI:

http://dx.doi.org/10.5038/1911-9933.9.1.1263

Available at: https://digitalcommons.usf.edu/gsp/vol9/iss1/7

This Articles is brought to you for free and open access by the Open Access Journals at Digital Commons @ University of South Florida. It has been accepted for inclusion in Genocide Studies and Prevention: An International Journal by an authorized editor of Digital Commons @ University of South Florida. For more information, please contact digitalcommons@usf.edu. 


\section{"Liberat[ing] Mankind from such an Odious Scourge": The Genocide Convention and the Continued Failure to Prevent or Halt Genocide in the Twenty-First Century}

\section{Acknowledgements}

I would like to thank Aristotle Kallis for his invaluable insights, support and guidance in writing this article. This work was supported by the Economic and Social Research Council [ES/J500094/1]. 


\title{
"Liberat[ing] Mankind from such an Odious Scourge": The Genocide Convention and the Continued Failure to Prevent or Halt Genocide in the Twenty-First Century
}

\author{
Kelly Maddox \\ Lancaster University \\ Lancaster, United Kingdom
}

\begin{abstract}
Since it came into force in 1951, the United Nations' Convention on the Prevention and Punishment of the Crime of Genocide, a document created with the explicit purpose of "liberat [ing] mankind from such an odious scourge," has largely failed to deliver on the promises it enshrined. The twentieth century bore witness to an increasing frequency of genocides, a pattern which is continuing into the twenty-first century with the outbreak of arguably genocidal violence in Darfur in 2003, and more recently, the Central African Republic (CAR) in 2014. This article analyzes the failure of the Genocide Convention by exploring its deficiencies alongside issues of state sovereignty and levels of political interest, and particularly, the relationship between these issues, in the context of the specific cases of Cambodia, Rwanda, and Darfur. Understanding the lessons of these past failures is crucial as the UN attempts to address genocidal violence in the CAR today.
\end{abstract}

Keywords: definition, genocide, Genocide Convention, prevention, state sovereignty

The creation of the United Nations' Convention on the Prevention and Punishment of the Crime of Genocide ${ }^{1}$ (Genocide Convention) in 1948 was, as Mr. Evatt, then-President of the General Assembly observed, an "epoch-making" event for "a significant advance had been made in the development of international criminal law." ${ }^{2}$ Certainly, it was a landmark document being one of the first of its kind to address human rights issues. More importantly, with its moral obligation for signatories to prevent genocide, it was unique in its scope and in its potential as a tool that could be utilized by the UN, and the international community, when faced with cases of potential, or unfolding, genocide. Thus, it went much further than any other international criminal law document at that time. Nevertheless, the Genocide Convention was not without its flaws. Debates over several controversial yet significant aspects continued over the two years of drafting resulting in an ambiguously worded, loop-hole ridden diplomatic compromise. This was a necessity for, as the Australian delegate Mr. Dignam noted, waiting to satisfy the arguments of all fifty-eight member states "would be tantamount to postponing the completion of the instrument indefinitely." ${ }^{3}$ From the outset, the Convention was seen by its own creators as an incomplete compromise, a starting point which they hoped, "in spite of its imperfections...could not fail to have a preventive effect." 4

The record of the Genocide Convention since it came into force in 1951 would seem to suggest otherwise. ${ }^{5}$ In fact, as the Cold War began to dominate the international arena, it went through a "lengthy hibernation." ${ }^{6}$ Unfortunately, the same could not be said of genocide itself. Instances of genocidal violence occurred unimpeded throughout the period. The most well-known case is that which took place in Cambodia between 1975 and 1979, where the calculated slaughter and starvation of up to twenty percent of the population went largely unacknowledged, and definitely unrestrained, until the controversial Vietnamese invasion of 1978 thrust it to the forefront of world affairs. ${ }^{7}$ With the end of the Cold War came increased optimism as a "new world order" was to be established hopefully bringing greater success for the UN. On 13 January 1992, British Foreign Secretary, Douglas Hurd suggested that "now the Cold War is over, the UN, and particularly the Security Council, is working as the founding fathers intended." ${ }^{8}$ If the founding fathers had intended for the UN to stand idle as the perpetration of brutal atrocities shattered the lives of hundreds of thousands of victims around the world, then it certainly was. For the end of the Cold War had also "lifted the lid" on "simmering tensions" around the world. ${ }^{9}$ Horrific genocidal violence erupted first in the former Yugoslavia in 1992 and then Rwanda in 1994. These cases emphasize that despite early optimism, the Convention still remained mostly impotent in regards to prevention. Indeed, the odious scourge has continued into the twenty-first century where, in spite of initiatives such as the Responsibility to Protect (R2P) and the creation of the Office of the Special Advisor on the Prevention of Genocide (OSAPG), genocidal violence has continued on and off in Darfur, Sudan since 2003.

Kelly Maddox, "'Liberat[ing] Mankind from such an Odious Scourge': The Genocide Convention and the Continued Failure to Prevent or Halt Genocide in the Twenty-First Century" Genocide Studies and Prevention 9, 1 (Spring 2015): 48-65. @2015 Genocide Studies and Prevention.

http://dx.doi.org/10.5038/1911-9933.9.1.1263 
More recently, UN spokespeople have been warning of looming genocide in the Central African Republic (CAR). Sectarian violence, largely between Christian and Muslim groups, broke out in 2013 following the overthrow of President François Bozizé by Michel Djotodia, leader of Muslim rebel group, Séléka, on 24 March. ${ }^{10}$ Despite the official disbandment of Séléka and the eventual resignation of Djotodia on 11 January 2014, horrific violence continued to engulf the country following the rise of the Christian militia group, anti-balaka. ${ }^{11}$ Amnesty International reported massacres that had caused Muslims to begin fleeing the country ${ }^{12}$ and in the same month, John Ging, director of operations for the UN Office for Co-ordination of Humanitarian Affairs, warned that, "it has all the elements that we have seen elsewhere, in places like Rwanda and Bosnia...the seeds are there, for a genocide. There's no question about that."13 Secretary-General, Ban Ki-moon, also raised the specter of genocide, when in April he cautioned that, having failed the people of Rwanda twenty years before "we are at risk of not doing enough for the people of the CAR today." ${ }^{14}$ In July 2014, a ceasefire agreement was rejected by Séléka rebels and October saw a resurgence of violence that has continued into $2015 .{ }^{15}$

The threat of genocide in the CAR is very real. However, after almost two years of violence, the Genocide Convention appears to remain as impotent as ever, while the international response echoes past failures. In this article, I revisit the responses to past cases exploring, in particular, the failure to prevent or halt genocide in Cambodia, Rwanda and Darfur. Since the constraints of this article preclude in-depth analysis of a vast array of cases, I have selected these instances as representative of failures from the Cold War period, the more humanitarian oriented 1990s and the post-Rwanda years in order to highlight how the Convention has been used, or more often not used, in preventing and halting genocide. By focusing on individual cases from these different periods, I contextualize these responses within their individual political climates. I argue that the failure of the Genocide Convention is the result of complex, inter-related factors, including those related to state sovereignty and levels of political interest which impact on, and are in turn influenced by, the Convention's own deficiencies in a somewhat trilateral relationship. Understanding past failures in terms of this relationship is crucial as the international community grapples with the challenges of potential genocide in the CAR today.

\section{Pawns on a Chessboard: Cambodia}

The Cold War era has aptly been described as a period in which no more than "lip-service" was paid to human rights which generally took a backseat as bipolar politics dominated international concerns. ${ }^{16}$ Nowhere is this more evident than in one of the most infamous cases of human rights abuses of this period, abuses that have largely been acknowledged as genocide. Between 1975 and 1979, the communist Khmer Rouge (KR), under the leadership of Saloth Sar, more commonly known by the pseudonym Pol Pot, staged a revolution in Cambodia which "turned back Cambodian clocks to year zero." ${ }^{17}$ Over the next few years, Cambodians were systematically slaughtered and starved to death under a ruthless regime which aimed to transform the country into a utopian, agrarian society and which would target for elimination any "undesirable elements." ${ }^{18}$ Following a series of border skirmishes which had begun in early 1977 and had escalated to war by the end of the year, Vietnamese troops invaded Democratic Kampuchea (DK) on 25 December 1978. Over a course of two weeks, they had secured the capital Phnom Penh and installed a Vietnamese-supported government as the KR fled across the border into Thailand. ${ }^{19}$ The invasion catapulted the previously neglected situation in Cambodia to the forefront of world affairs and became the subject of heated debate within the UN's Security Council. The Vietnamese Government justified their response as self-defense in the face of KR and Chinese aggression which they claimed threatened their survival and, as the true extent of atrocities was revealed, began to emphasize the humanitarian outcome as further validation for the invasion. ${ }^{20} \mathrm{DK}$, represented by Prince Norodom Sihanouk, described the regime as victim to the "flagrant aggression" of Vietnam who had used "Hitlerite" methods in their "colonial conquest" of Cambodia. ${ }^{21}$

The position of the major powers in these debates was largely motivated by the political circumstances in Southeast Asia and their corresponding realpolitik interests. From the 1960s, Indochina had become a battlefield for influence between China and the Soviet Union. Vietnam had grown closer to the Soviet Union during its war with the US and China responded to this 
by attempting to increase its influence in Laos and Cambodia, aiding the communists in both countries. ${ }^{22}$ The survival of DK in the late 1970s was in large part due to aid provided by the Chinese and similarly, by 1978, Vietnam had come to depend on the Soviet Union. ${ }^{23}$ The debates reflected these divisions and alliances. The Soviet Union took up the humanitarian arguments of the Vietnamese, referring to atrocities as a "policy of open genocide." ${ }^{24}$ On the opposite side, China simply avoided discussion of human rights abuses focusing instead on condemnation of the invasion arguing that with the "powerful support" of the Soviet Union, Vietnam had barbarously breached Cambodian sovereignty in their first steps at creating a colonial empire. ${ }^{25}$ The stance of the US was similarly influenced by political context. Following their defeat in the Vietnam War in 1975, they had mostly withdrawn from the region and had been against any involvement that may have led to another conflict. ${ }^{26}$ Nevertheless, they had discreetly supported the KR. In a meeting with Thai Foreign Minister, Chatichai Choonhavan, in November 1975, Secretary of State, Henry Kissinger, acknowledged that the KR were "murderous thugs" but noted that the US would "be friends with them" as they were needed as a barrier against Vietnam. ${ }^{27}$ Furthermore, in the 1970s, they had been attempting to develop friendly relations with the Chinese government, and were naturally inclined against their ideological, and former, enemies, the Soviet Union and Vietnam, respectively. Thus, alongside China, they supported the genocidal regime. ${ }^{28}$

However, the US, along with others that continued to support the KR, could not completely ignore discussion of atrocities as they had submitted reports and condemned DK for human rights abuses through 1978. Indeed, the Soviet Union had directly quoted from a statement circulated by President Carter on 21 April, in which he stated that "America cannot shirk its duty to condemn the Cambodian Government.... Thousands of refugees from Cambodia accuse their own Government of destroying hundreds of thousands of inhabitants as a result of the policy of genocide." ${ }^{29}$ The US was forced to acknowledge that human rights abuses had occurred but also argued that such abuses did not justify the breach of Cambodian sovereignty. ${ }^{30}$ This was to be the stance of the majority of delegates. The debates centered predominantly on Cambodian sovereignty with no discussion of the genocidal violence that, in spite of underlying motives, was halted by the Vietnamese invasion. Essentially, the bipolar political circumstances of the time meant that Cambodia was a pawn on the superpower's chessboard more than a legitimate human rights concern. ${ }^{31}$ As Michael Reisman has argued, most states were "more concerned with protecting Cambodian sovereignty than with preventing that sovereignty from being used to murder over a million human beings." ${ }^{32}$

It was this kind of situation that had led Raphael Lemkin, who had coined the term "genocide" in 1944 and was a key figure in the creation of the Genocide Convention, to direct his crusade for international legislation against the crime. The concept of state sovereignty, which allows states to conduct their internal affairs free of external interference permitting leaders to exercise power within their own borders unimpeded and with impunity, evolved and became entrenched after the Treaty of Westphalia in $1648 .{ }^{33}$ Lemkin argued against the idea of absolute sovereignty stating that it could not be "conceived as the right to kill millions of innocent people." ${ }^{34}$ Due largely to his efforts, the end of the Second World War saw an erosion of this notion as the Nuremberg trials became the first to successfully punish perpetrators under international law. The Genocide Convention was created within this context and with its obligation to prevent and punish genocide offered a direct challenge to state sovereignty. However, it is a concept that continues to be a cornerstone principle of the UN and therefore, there are inherent complications with the role of the UN as both a defender of sovereignty and an organization committed to preventing and halting genocide. Article 2(7) of its Charter stipulates that it is not authorized to intervene "in matters which are essentially within the domestic jurisdiction of any state" ${ }^{\prime \prime 3}$ while Articles I and VIII of the Genocide Convention oblige the UN and the international community to become involved in the domestic affairs of others when faced with genocide, implying the necessity of intervention. The complications that arise from this inherent contradiction are exacerbated by the failure to clarify what constitutes appropriate prevention as required by the Convention, with further difficulties arising in determining when and if taking action to prevent or halt genocide is legitimate. Ultimately, the problem of sovereignty in relation to prevention and intervention, as Bruce Cronin has argued, lies in having to navigate this tension. ${ }^{36}$ 
In the case of Cambodia, the tension was avoided as the Genocide Convention lay forgotten in favor of the Charter of the UN which was cited extensively in the debates. Even if the Convention had been discussed, responses from delegates suggest that the ambiguities of Articles I and VIII would have been manipulated to allow DK sovereignty to have remained sacrosanct. Certainly, the delegate from Portugal made this clear when he stated that, "there are no nor can there be any socio-political considerations that would justify the invasion of the territory of a sovereign State by the forces of another State." ${ }^{137}$ Moreover, despite the Commission on Human Rights (CHR) March 1979 judgment that the situation in DK had "constituted nothing less than autogenocide" and "the most serious [events] that had occurred anywhere in the world since Nazism," ${ }^{38}$ in its thirty-fourth session in November that same year, the General Assembly issued a resolution which ignored any mention of genocide but "deeply regret[ed] the armed intervention by outside forces in the internal affairs of Kampuchea," reiterating, "that all States shall refrain...from the threat or use of force against the sovereignty, territorial integrity or independence of any State, and strictly adhere to the principles of non-interference in the internal affairs of other States. ${ }^{\prime 39}$ As Leo Kuper argued, despite evidence of genocide, the UN remained a champion of state sovereignty, ${ }^{40}$ a response in line with its role in maintaining international peace, but at odds with the promises, both preventive and punitive, of the Genocide Convention. ${ }^{41}$ However, though they had mentioned genocide, neither Vietnam nor the Soviet Union drew on the Convention to legitimize or justify the invasion and their arguments were further weakened since the doors of DK between 1975 and 1979 had restricted the flow of information coming out of the country.

On coming to power in April 1975, the KR immediately expelled all foreign nationals. The borders remained closed until March 1978 when three Western journalists were permitted a guided visit. ${ }^{42}$ Consequently, the only information coming out of the country was from the KR controlled radio station Voice of Democratic Kampuchea and from refugees that escaped into Thailand. ${ }^{43}$ The situation was viewed through a narrow lens and it was difficult for the international community to fully comprehend the true nature of the regime. Indeed, those involved in the anti-war movement, such as Noam Chomsky, questioned the validity of reports of atrocities, claiming that they had been exaggerated to justify another war in Southeast Asia. ${ }^{44}$ Nevertheless, reports and stories of atrocities increased over the years and as mentioned, President Carter began speaking of genocide in early 1978. In March that year, the CHR invited comments and observations "relating to the human rights situation" in DK and several states submitted extensive reports, the submission from Canada explicitly referring to genocide. ${ }^{45}$ These documents were then passed to the SubCommission on Prevention of Discrimination and Protection of Minorities to further analyze in preparation for their next annual meeting. ${ }^{46}$ The KR, having been invited to comment, rejected the investigation as "impudent interference" in their internal affairs and warned that it would "not tolerate any affront" to its sovereignty. ${ }^{47}$ By the time it was back on the CHR's agenda in March 1979, they had been overthrown. In January 1979, only Vietnamese and Soviet officials had visited Cambodia and witnessed the devastation wrought there. ${ }^{48}$ As it was, the majority of delegates were less inclined to take them at their word, the delegate from Portugal lamenting that, "had Kampuchea been an open society, all the claims now made of invasion would have been instantly verified. The Pol Pot government certainly had good reasons not to allow the outside world to know what was happening in its own country, and the price for this is always heavy." ${ }^{49}$ The CHR report, curiously ignoring the documents it had collected in the previous year, also claimed that "there was no proof [of atrocities]...since there had been no investigation by the United Nations." 50

State sovereignty became a hindrance then, allowing the KR to obstruct access to the country and impede the collection of accurate information which delayed discussions and meant that intervention and not prevention was required. The political context was not one conducive to intervention and the Vietnamese invasion forced tensions between state sovereignty and humanitarian intervention to the surface. In the subsequent debates sovereignty, as defined and rooted in the principles of the UN Charter, was used as a tool by those who opposed Vietnam, while those that supported the invasion failed to mobilize the Genocide Convention and its potential for legitimizing the overthrow of a genocidal regime. In the context of the Cold War, the main concern lay with keeping the peace in an unstable region between smaller states that had more powerful allies. As such, primacy was afforded to state sovereignty even when there 
was substantial evidence of genocidal acts. This suggests that the primary obstruction in this case was the political context and resulting interests of the main powers involved who were able to manipulate and use state sovereignty to their advantage. However, as Paul Bartrop has pointed out, the concept of sovereignty is a central underlying feature of realpolitik and national interest. ${ }^{51}$ The ideals and principles behind state sovereignty inform and shape politicians' understanding and definition of what lies within their national interests, and thus, the two cannot be separated. The Genocide Convention was intended to mitigate the absolute nature of this relationship to ensure that sovereignty as a natural right and interest of states could not be used to justify or impede the prevention or halting of genocide. However, its effectiveness lies in the balance between the UN as an international organization for the defense of sovereignty and the UN as committed to the promise of "never again." In the political context surrounding genocide in Cambodia, the former took precedence and consequently, the Convention lay forgotten.

\section{A New World Order?: Rwanda}

The end of the Cold War saw a redefinition of the UN's role in ensuring peace and security, moving away from a focus on keeping the peace between states, to keeping the peace within states. ${ }^{52}$ This ushered in a new era of optimism in terms of the UN's effectiveness in its humanitarian endeavors and, to an extent, eroded the concept of state sovereignty. In this environment, responses to genocide in Rwanda should have been more amenable to prevention or intervention. As a smaller, poorer country, it was less "sovereign" than powers that were stronger militarily and economically. ${ }^{53}$ It was not a pawn on a "superpower chessboard" and, except for France, none of the other permanent five members of the Security Council had any direct interest in Rwanda. This lack of interest was to prove equally disastrous for prevention for most scholars agree that, when faced with perhaps the clearest case of genocide since the Holocaust, the international community could simply not muster the will to act. What perhaps makes this particularly shameful is that, while the impact of state sovereignty, in terms of limiting available information and obstructing access to the country, meant that Cambodia was always going to be a case of intervention, Rwanda has since been acknowledged as a genocide "both foreseen and flagged" and thus, entirely preventable. ${ }^{54}$

Indeed, though the initial trigger for the genocide was the death of Rwandan President Juvénal Habyarimana when his plane was shot down on 6 April 1994, the tensions that underscored the brutal slaughter that followed this incident had been a consistent problem since the country became independent in $1962 .{ }^{55}$ Frictions between different groups in Rwanda became entrenched and exacerbated by colonial rule in the early twentieth century which had established a hierarchal style society based on, what they perceived to be, "scientific" understandings of ethnicity placing the Tutsi as politically superior to the Hutu and Twa groups..$^{56}$ The "Hutu Revolution" between 1959 and 1961 overturned this system, leading to an eruption of violence during which the Hutu majority came to power and many Tutsi fled the country. Following this, Michael Barnett argues, ethnic violence became a central facet of Rwandan politics. ${ }^{57}$ Through the 1960s, Tutsi refugees unsuccessfully attempted to force their way back into Rwanda and the Hutu government responded viciously leaving over 20,000 Tutsi dead and 300,000 in exile. ${ }^{58}$ Violence flared up again in 1990 after the Rwandan Patriotic Front (RPF) invaded the country to further its primary goals of repatriating Tutsi refugees and establishing a power-sharing government. After thirteen months of negotiation, the Arusha Accords were signed in August 1993 and the UN established the United Nations Assistance Mission in Rwanda (UNAMIR), consisting of a force of 2,548 peacekeepers, to monitor the ceasefire agreement. ${ }^{59}$ Despite an apparent end to the dispute, a UN commissioned report investigating the human rights situation submitted in August 1993 by Bacre Waly Ndiaye warned of genocide based on massacres and human rights violations that had occurred throughout the year. Ndiaye suggested that "genocide" might be applicable because of a pattern of systematic attacks that had been directed against "Tutsis in the overwhelming majority of cases." ${ }^{60}$ The recruitment and training of the Interahamwe militias, the distribution of arms, and propaganda inciting discrimination and extermination of Tutsi, were further indications of impending violence, if not genocide. ${ }^{61}$ Perhaps the clearest warning, however, was given in January 1994 when commander of UNAMIR, General Roméo Dallaire, received insider information that Hutu extremists were planning an extermination campaign. In response, Dallaire requested authority to seize caches of machetes and other weapons 
but was denied on the basis that such action was beyond UNAMIR's Chapter VI mandate. ${ }^{62}$ Despite early warning and opportunities for prevention, the genocide began on 7 April and over a period of one hundred days, over 800,000 Tutsi and moderate Hutus were systematically targeted and killed. ${ }^{63}$

Having failed to prevent genocide prior to the outbreak of violence, the international community maintained a policy of inaction delaying intervention until the genocide was already over. This response is largely seen to be a result of a general indifference or a lack of political will to intervene. Jared Cohen, for example, describes the US response as one of "one hundred days of silence," a description that Linda Melvern would probably agree applies to Britain as well. ${ }^{64}$ Undoubtedly, in the midst of a series of crises in Bosnia, Haiti, and North Korea, and with elections in South Africa, Rwanda was seen as a low priority. Furthermore, UN resources were stretched thin as they were engaged in peacekeeping missions throughout the world with over 71,000 troops committed in seventeen problem areas. ${ }^{65}$ Added to this were the repercussions of a disastrous peacekeeping mission in Somalia the year before. A UN-led mission to establish peace in Somalia resulted in the deaths of twenty-four Pakistani peacekeepers on 5 June 1993 and subsequent attempts to apprehend those responsible ended with the deaths of eighteen American rangers. ${ }^{66}$ The domestic fallout from events in Somalia saw a dramatic shift in US policy away from a broad definition of national interest and expansion of the US' role in peacekeeping as outlined in Presidential Review Decision 13, to a more restricted and selective policy of intervention described in Presidential Directive Decision 25. ${ }^{67}$ Somalia similarly influenced the UN's approach with Secretary-General Boutros Boutros-Ghali advising African leaders in October 1993 that the role of the UN was to maintain peace, not to impose it. ${ }^{68}$ The legacy and risks of another Somalia hung over Rwanda and despite the shift towards humanitarian intervention after the end of the Cold War, the global context in April 1994 was not one that produced a strong will to intervene.

Moreover, as Frank Chalk and others suggest, politicians assessed their response on the basis of national interest and whether intervention would result in domestic political opposition. ${ }^{69}$ The Clinton Administration did not want a repeat of Somalia and the British government's reluctance was influenced, according to an off-the-record interview with a foreign office insider, by a lack of interest from the British press and public. ${ }^{70}$ It was not just indifference, but a national interest that went against intervention that caused the US and the UK to lead the Security Council in its avoidance of intervention. The policy was not one of complete inaction though, for after the death of ten Belgian peacekeepers on 7 April, a concerning reminder of events in Somalia, they were able to efficiently and effectively secure the resources and supplies for the safe evacuation of all foreign nationals. ${ }^{71}$ Both the US and the UK then successfully lobbied for the withdrawal of UNAMIR and on 21 April the Security Council adopted Resolution 912 reducing forces on the ground to an ineffective 270 peacekeepers. ${ }^{72}$ It was not until after 6 May, a month into the genocide, that the Security Council was finally willing to reconsider its stance and provide "urgent and effective means of action." Boutros-Ghali recommended a force of 5,500 troops, the same number that Dallaire had consistently requested in order to halt the genocide in early April. ${ }^{73}$ Discussions, debates and delay tactics continued, however, until 17 May when Resolution 918, agreeing to an increase of the UNAMIR force, was adopted. ${ }^{74}$ Unfortunately, the UN relied on states donations which were not forthcoming and continued delays over supplying troops and equipment meant that the force did not arrive in Rwanda until the genocide had come to an end in July, through the efforts of the RPF. ${ }^{75}$

The deliberate inaction of the international community was a response defended and rationalized by the avoidance of the term genocide which many believed would have invoked the Convention and its perceived obligations to prevent. ${ }^{76}$ Though some officials might argue that they could not have predicted genocide and that they had no idea what was happening, evidence suggests that violence in Rwanda was recognized as genocide early on and that, despite this, many politicians refrained from using the word publicly. ${ }^{77}$ Instead, the situation was distorted in the media through its representation as an African civil war and a product of "ancient tribal rivalries." 78 The failure of the media to convey the magnitude of the situation allowed politicians to continue to downplay the genocide and in fact, the perception of the situation in Rwanda as a civil war aided the US and the UK in their arguments for pulling peacekeeping troops out of a place where, they reasoned, there was no peace to keep. ${ }^{79}$ Discussions over the use of the term genocide did not take place in the Security Council until the end of April. Some in the Council supported its use and the 
President drew up a statement that explicitly described the situation as genocide, however; this reference was later removed due to the opposition of some states, namely the US and the UK. ${ }^{80}$ The US argued that "events in Rwanda clearly seem to meet the definition of genocide" but noted that "if the council acknowledges that, it may be forced to 'take such action' as provided for in Article VIII." ${ }^{81}$ The British ambassador, David Hannay, further emphasized that if the Council used genocide and did not act it would be seen as ridiculous and would become a "laughing stock." 82 As Barnett has argued, "the UN was caught between the force of moral obligation and the reality that it was not going to deliver a rescue operation." ${ }^{83}$ It was embarrassment by the continued use of genocide by other world leaders and human rights organizations, such as Oxfam and Human Rights Watch that eventually led the Security Council to consider taking action on 6 May, although it took until 10 June for US officials to be allowed to fully use the term "genocide." 84

The reluctance to use the rhetoric of genocide was due to a perception that invoking the Convention would oblige states to intervene. However, this obligation is actually more moral than legal. The response of the international community would seem to suggest that the ambiguous wording of the preventive provisions of the Convention were interpreted as requiring full military intervention when actually that obligation could entail the use of "soft options." For example, Helen Fein suggests that the suppression of Radio Television Libre des Milles Collines would have been a cheap and effective method of preventing "direct and public incitement to commit genocide." 85 Nevertheless, the international community favored an all or nothing interpretation of the Convention's obligations which impeded action as states were unwilling to entertain the idea of military intervention. ${ }^{86}$ Furthermore, definitional ambiguities in the wording of the Convention, a problem to be discussed later in this article, enabled those that wished to avoid saying genocide to do so. US State Department spokesperson, Christine Shelly, dodged direct reference to genocide stating that it "has a very precise legal meaning...Before we begin to use [the] term, we have to know as much as possible about the facts of the situation, particularly about the intentions of those who are committing the crimes" She further reasoned that "the intentions, the precise intentions, and whether or not these are directed episodically or with the intention of actually eliminating groups in whole or in part, is a more complicated issue to address...It's something that requires a very careful study before we can make a final determination." ${ }^{87}$ Shelly clearly exploited the Convention's ambiguities to the advantage of those who did not wish to invoke it, making the determination of genocide seem like a legitimately more complicated and long drawn-out process than it reasonably should be.

Thus, even in the more humanitarian oriented 1990s, the realpolitik, national interests of states hindered the prevention and halting of genocide. Whereas Cambodia had been a pawn between major powers that had significant involvement in the region, Rwanda suffered from the opposite. Of the permanent five, only France had any direct interest there and in a context where the UN was engaged in multiple missions throughout the world, one of which, a year before had gone disastrously wrong, politicians in the US and the UK were unwilling to risk the domestic backlash should they commit to another peacekeeping mission that may go awry. For very different reasons, political interest was a hindrance to the effectiveness of the Genocide Convention. In this case, the Convention was not forgotten, though not formally invoked, and its deficiencies played into the hands of those attempting to avoid what they considered to be an obligation to "do something." While a lack of political interest as influenced by realpolitik can impede the effectiveness of the Genocide Convention as states are reluctant to act unless prevention or intervention is within their national interest, the deficiencies of the Convention intensify this problem by allowing and enabling politicians to manipulate and exploit the very tool that should encourage action. ${ }^{88}$ Furthermore, the failure to clarify the nature of the obligation to prevent and to give an idea of the ways in which preventing or halting genocide might be enacted outside of military intervention exacerbated the lack of will to intervene as politicians deliberately sought to avoid the perceived obligation to commit militarily in Rwanda.

\section{"Never Again," Again: Darfur}

After the failure in Rwanda, as well as Bosnia, in the 1990s, the UN and the international community reaffirmed their commitment to the promise of "never again" and small steps were 
taken to overcome some of the issues of preventing and halting genocide. In 2001, the International Commission on Intervention and State Sovereignty, established by the Canadian government in 2000, issued its report which promoted the R2P concept. This framed the underlying principle of state sovereignty not as control over one's people but as a responsibility to one's people. More importantly for prevention, however, R2P acknowledged that, should a state fail in its responsibility, by being unwilling, unable or the perpetrator, then that responsibility would fall to the international community as a whole. ${ }^{89}$ This was aimed at easing issues of sovereignty by giving priority to the state to prevent atrocity crimes within its borders and by justifying the involvement of the international community in its internal affairs if it failed to do so. These principles were reaffirmed at the 2005 World Summit and the Secretary-General has since been working towards further clarifying and developing an understanding of the obligations and actions required by the international community as entailed by R2P. ${ }^{90}$ In addition, in 2004, the Secretary-General created the OSAPG, which became a fulltime position in 2007, to address previous limitations in efforts to prevent genocide. ${ }^{91}$ The Special Adviser on the Prevention of Genocide's (SAPG) mandate was, according to Juan Méndez, the first to act in this role, to focus on how to prevent genocide by "gathering information, providing early warning and presenting appropriate recommendations to prevent a situation from degenerating into genocide." ${ }^{12}$ It has also created an extensive and flexible framework for analyzing and identifying potential cases based on the definition offered in the Convention, has monitored and provided recommendations on situations in various countries and, in doing so, has had some successes.$^{93}$ Nonetheless, although promising, it is within the context of these initiatives that genocide in Darfur, Sudan has continued unimpeded since 2003. While analysis of Cambodia and Rwanda have emphasized the role of particular factors, namely state sovereignty and level of political interest, Darfur is the first case in which the Convention was officially invoked and directly applied to an on-going genocide and is thus, an excellent example of its inherent deficiencies. ${ }^{94}$

Violence in Darfur broke out in early 2003 following attacks on government military forces by rebels of the Sudan Liberation Army/Movement (SLA/M) and Justice and Equality Movement (JEM). The Government of Sudan (GoS) responded with a devastating counter-insurgency campaign, supporting Janjaweed militias in their desolation of Darfur. ${ }^{95}$ These militias have systematically targeted Black African Darfuris, predominantly from the Fur, Masalit and Zaghawa tribes, razing villages, killing large numbers of civilians and engaging in mass rape of women and girls. ${ }^{96}$ Though violence was triggered by the armed rebellion of SLA/M and JEM in early 2003, like Rwanda, it has complex, more long-term, and varied origins. ${ }^{97}$ Since the 1980 s, ethnic tensions have been exacerbated by a changing climate which saw drought, famine and desertification push what, superficially, can be categorized as Arab, nomadic herders and Black African, sedentary farmers into competition for increasingly scarce resources. ${ }^{98}$ Attempted mediation by the GoS often saw the Arab-dominated government typically favor Arab herders over Black Africans and, as conflict has continued, the government has supplied weapons and provided assistance to Arabs in the region. ${ }^{99}$ Conflict within Sudan, as well as in neighboring regions, has also aggravated the situation and hindered early preventive action. An Arab supremacist ideology imported from Chad and Libya has intensified government favoritism toward the Arab groups and the involvement of Chad in the rebellion, in terms of supplying arms and assistance, has increased factionalism within the rebel groups which has obstructed attempts to establish and maintain peace. ${ }^{100}$ Civil war between North and South Sudan has also intensified frictions as both the GoS and Sudan People's Liberation Army/Movement (SPLA/M) have provided supplies and financial assistance to groups in Darfur in order to enhance their respective causes. When, in 2001, the government and SPLA/M entered into peace talks in Naivasha, at which Darfur was not represented, rebel groups became concerned over being left out of decisions that would shape the future Sudan and staged an uprising in response. ${ }^{101}$ As René Lemarchand suggests, the signing of the Comprehensive Peace Agreement in January 2005 officially ending the civil war, and paving the way for independence for South Sudan, may also have impeded peace efforts as rebels attempt to force a similar agreement. ${ }^{102}$

The civil war has also overshadowed violence in Darfur as media reportage focused on the peace talks. ${ }^{103}$ It was not until March-April 2004 that Darfur began to capture media attention after a speech by UN Humanitarian Coordinator, Mukesh Kapila, on 19 March 2004, associated the 
violence with the Rwandan genocide. ${ }^{104}$ Public awareness dramatically increased and, during the following months, responding to domestic activism and pressure, US politicians gradually began to discuss Darfur in relation to genocide. ${ }^{105}$ An investigation was launched which, after interviewing 1,136 Darfuri refugees in internally displaced persons (IDP) camps in Chad, found a "consistent pattern of atrocities" directed against the non-Arab ethnic groups in Darfur. ${ }^{106}$ Based on these findings, Secretary of State Colin Powell declared before the Senate Foreign Relations Committee, on 9 September that, "genocide had been committed... and may still be occurring." Accordingly, under Article VIII of the Genocide Convention, he called on the UN to launch "a full-blown and unfettered investigation." ${ }^{107}$ On 18 September, the UN, responding to these recommendations issued Security Council Resolution 1564 which established a Commission of Inquiry (COI) to investigate atrocities in Darfur. ${ }^{108}$ The COI conducted its investigation in Sudan between November 2004 and January 2005 and, contrary to the US finding, declared that the "Government of Sudan had not pursued a policy of genocide," although recognized that "gross violations of human rights" had been perpetrated, including crimes against humanity and war crimes. ${ }^{109}$

The fact that the US and UN arrived at such divergent conclusions, while possibly influenced by differences in methodology, rigor, and thoroughness in their respective investigations, ${ }^{110}$ is also a result of the definitional ambiguities in the Genocide Convention. Article II of the Convention offers a list of acts that might be considered genocide if "committed with the intent to destroy, in whole or in part, a national, ethnical, racial or religious group, as such." It offers no further clarification for how such intent might be determined, whether "in whole or in part" should refer to the intent to destroy or to the actual destruction of a group, or how "in part" might be either quantified or qualified. Consequently, the Convention's ambiguous wording proved problematic when invoked in relation to Darfur. The wording "in whole or in part" was found to be straightforward when applied to actual, physical destruction and both investigations concluded that atrocities were sufficiently "widespread," "systematic," and "large scale."111 However, "in whole or in part" as it pertained to the "intent to destroy" proved to be a point of contention. The US investigation found that "evidence corroborates the specific intent of the perpetrators to destroy a group 'in whole or in part"' and that "intent may be inferred from their deliberate conduct."112 In contrast, the COI found that "the crucial element of genocidal intent appears to be missing" This was argued on the basis of "several indicators" such as "the fact that...attackers refrained from exterminating the whole population...but instead selectively killed groups of young men"113 The COI focused predominantly on killing as opposed to other methods of genocide and imposed a higher threshold of interpretation than the US investigation had, understanding genocidal intent as meaning the intent to destroy the group "in whole" rather than "in part," an interpretation at odds with the jurisprudence of international law. ${ }^{114}$ In his analysis of the UN's investigation, Samuel Totten suggests that the COI may have been biased towards a finding against genocide from the start. ${ }^{115}$ If this was the case, then the ambiguities of the Convention certainly assisted its manipulation of the definition of genocide so as to arrive at the desirable conclusion.

In addition to its ambiguous wording, limiting protected groups to just national, ethnic, racial, or religious groups has created difficulties. Aside from the obvious problem of excluding certain groups from protection, which Chalk and Kurt Jonassohn argue meant that prior to the 1990s the UN had not denounced any genocidal killings as genocide, ${ }^{116}$ this limitation means that for a finding of genocide, it must be ascertained whether the victims constitute one of the protected groups and whether they were targeted with the intent to destroy them as part of that group. This is exacerbated by the Convention's failure to provide definitions for terms which have complex and mutable identities. As Chalk and Jonassohn have emphasized, the terms national, ethnic, racial, and religious are historically and culturally dependent and have fluid meanings that can differ over time and across cultures. ${ }^{117}$ There are inherent complications involved in identifying groups that rarely meet neat, objective definitions. Moreover, there are questions over who should define the group identity. Should this be an objective party such as the UN, scholars, or politicians, or should it be a subjective one such as the victim group or the perpetrators themselves? More importantly, what happens when the definitions of the subjective approach do not meet those of the objective approach?

These issues are highlighted by Darfur where the identification of victim and perpetrator groups proved difficult since to an outsider there seemed to be little to no difference between 
them. ${ }^{118}$ The US investigation had offered a broad interpretation defining victims simply as "nonArab" ethnic groups. ${ }^{119}$ However, the COI considered the issue in more depth noting that victims objectively do not appear to make up ethnic groups distinct from the perpetrators. ${ }^{120}$ Indeed, they shared a number of cultural characteristics. ${ }^{21}$ The COI took into account the perspective of both the perpetrator and victim group and found that individuals "have come to perceive themselves as either 'African' or 'Arab"' and consequently, victims "subjectively make up a protected group."122 This reasoning is based on jurisprudence established by the International Criminal Tribunals for Yugoslavia and Rwanda. ${ }^{123}$ Though they concluded that the group element was sufficient to find genocide, the COI's lengthy discussion of the topic is suggestive of the complex and timeconsuming difficulties inherent in identifying groups involved in genocidal violence, especially since, in most cases, these groups are likely to be subjective social constructions as opposed to objectively distinguishable categories. This obviously has potential to impact preventive efforts as a genocide determination is delayed while questions over the identification of a group and whether victims were targeted based on that membership are answered.

Definitional issues in the Convention create, as Scott Straus suggests, "debilitating debates" over whether a situation can accurately be described as genocide which prolongs and hinders preventive responses. Such debates typically distract from difficult, but more important, questions over what could and should be done to prevent or halt genocide. ${ }^{124}$ Furthermore, as Beth Van Schaack observes, the investigation and determination of genocide as a precursor to either prevention or intervention can be used as a delay tactic by those reluctant to act. ${ }^{125}$ By the time the US called on the UN, for example, genocide was already underway and, despite having already investigated the situation itself, asked the UN to investigate further and not to intervene. The apparent requirement of a determination of genocide prior to action by the international community is also potentially detrimental. Of course, Jerry Fowler is correct in his assertion that a determination of genocide does not result in direct action. ${ }^{126}$ However, the rhetorical power of "genocide," a power that other terms have failed to develop, has potential in terms of outraging, raising awareness and mobilizing support for action. ${ }^{127}$ Furthermore, the use of genocide can morally embarrass, and to an extent oblige, politicians who might otherwise seek to avoid efforts to prevent or halt genocide. Indeed, it was the memory of Rwanda that prompted George W. Bush to declare "not on my watch" in relation to Darfur. ${ }^{128}$ However, the characterization of violence as crimes against humanity and not genocide by the COI let the international community "off the hook" so to speak as it appears to have stymied media attention and public interest that had been gathering increased momentum through 2004. David Luban observes that media coverage largely misunderstood the findings leading to headlines such as "Murder - But No Genocide," and "Sudan: U.N. clears Government of Genocide" that contributed to a perception that crimes against humanity were not as bad, and also a belief that the UN had vindicated the GoS. ${ }^{129}$ Despite such increased activism after first declarations of genocide, the failure to legitimize those claims seems to have led to a general apathy that enabled the US to weaken its initial Darfur Accountability Act which had been established to bring in tough legislation against the GoS. ${ }^{130}$ It is impossible to determine the extent to which the COI's findings did impact action in Darfur. However, the implication is that at the very least it altered the perception of Darfur as an urgent crisis allowing politicians to remain reluctant to intervene and violence to continue unabated, fading into the background, described recently as a "forgotten genocidal war."131

In addition to definitional issues, the lack of clarification over what the obligation to prevent in Article I of the Convention entails also impedes its effectiveness in prompting successful prevention. This is emphasized by the responses of the US and UN to their respective investigations in Darfur. The US simply deferred the matter to the UN and Powell even made the point that other than this referral "no new action is dictated by this determination." 132 This response has been criticized by scholars, including Eric Reeves who suggested that Powell undermined the Convention by interpreting the obligation to prevent as entailing so little. ${ }^{133}$ Nonetheless, the ambiguous wording and failure to clarify the obligation to prevent means that the US interpretation, however distasteful, was valid within the terms of the Convention. The UN response was similarly disappointing. The COI seemingly noted the importance of action stating that "the international community cannot stand idle by, while human life and human dignity are attacked daily and on so large a scale in 
Darfur." One might have thought that such reasoning would conclude with recommendations for intervention. Incredibly, it did not. Instead, the COI recommended that the situation be referred to the International Criminal Court (ICC) for prosecution. ${ }^{134}$ This response reflects the punitive focus of the Genocide Convention and highlights the negative effect this can have on prevention and intervention. By approaching their investigation as a legal case, focusing on justice as if the genocide had concluded, the COI bypassed prevention, or rather by 2004, intervention, which gave the impression of constructive action, and may have contributed to a lack of forceful action that has allowed genocide in Darfur to continue relatively unobstructed. In July 2008, the ICC's chief prosecutor Luis Moreno-Ocampo did eventually petition the Court to issue an arrest warrant, including counts of genocide, for President Omar al-Bashir arguing that "his alibi was 'counterinsurgency'. His intent was genocide." 135 A warrant was issued in 2009, though the charge of genocide was conspicuously absent, however, al-Bashir dismissed the warrant as worthless. ${ }^{136} \mathrm{In}$ 2010, a second arrest warrant was issued, this time including genocide. ${ }^{137}$ However, since Sudan is not a signatory to the Rome Statute, the ICC can do little while he remains within Sudanese borders and under the protection of state sovereignty.

The specter of state sovereignty has also haunted efforts to bring genocide to an end in Darfur as the GoS continues to obstruct intervention. Since 2004, the GoS has attempted to force the removal of the African Union's Mission in Sudan (AMIS), ${ }^{138}$ has objected to a UN peacekeeping force, although Security Council Resolution 1769 establishing a hybrid UN-AU force (UNAMID), albeit with a watered-down mandate, was agreed in July 2007, ${ }^{139}$ has delayed deployment of peacekeepers and has frequently restricted peacekeepers' freedom of movement within the country. ${ }^{140}$ Since the issuance of the arrest warrant, it has further clamped down on movement and access in Darfur in order to prevent investigation of atrocities. More importantly, in 2009, the GoS expelled all foreign NGOs and has since used its sovereignty to block aid and access to IDP camps where food shortages and malnutrition have become increasingly worse. ${ }^{141}$ Despite R2P and a gradual erosion of the notion of absolute sovereignty then, the concept continues to allow al-Bashir to act with impunity, remains an impediment to efforts to halt violence in Darfur and is actually contributing to genocide by attrition.

That the GoS' sovereignty remains intact in spite of R2P and evidence of genocide is largely due to an international community that for all its rhetoric has expressed a lack of will to take a more robust approach. Indeed, though it led the way in first discussions of genocide and has implemented sanctions against GoS, the US response has been weak. This is largely due to the political context which saw Sudan become an ally in the US' war on terror after the attacks in September 2001. ${ }^{142}$ Furthermore, the context of the US invasion of Iraq in 2003 caused some countries to be cautious of US motives in declaring genocide in Darfur and as Eric Heinze observed, any involvement in another Arab nation's internal affairs without UN support was unlikely to have been well-received. In fact, the US was accused of using the rhetoric of genocide in relation to Darfur as a "pretext to invade another oil-rich and predominantly Arab and Muslim state."143 Securing UN support has been problematic since China and Russia, both of whom have vested interests in Sudan, have often abstained from votes and threatened the use of the veto on issues related to Darfur. Indeed, China has invested heavily in oil and other commercial developments importing two-thirds of Sudan's oil supply and, along with Russia, is one of the main suppliers of weapons to the government. ${ }^{144} \mathrm{In}$ addition to their diplomatic maneuvering, both countries continue to defy a UN arms embargo by supplying weapons and munitions that fuel the conflict. ${ }^{145}$ Such a context has given tacit support for the GoS allowing for the continuation of genocide under the protection of state sovereignty which is used to block the diluted measures that have been undertaken to bring violence to a halt. State sovereignty becomes quite the formidable barrier when the realpolitik interests of states create a lack of will to intervene.

Thus, while the Genocide Convention was invoked, its deficiencies have contributed to failures to halt genocide in Darfur. The lack of clarification over what the obligation to prevent entails has meant that US politicians could appear to act, easing domestic pressure, through referring the situation to the UN without actually taking action itself. Similarly, the punitive focus of the Convention has enabled the UN to 'act' by referring the situation to the ICC for punishment. Definitional ambiguities have enabled a dubious negative finding of genocide which stymied a 
rising activism and was again used as a delay tactic by those who wished to avoid action. Obviously, these failures cannot be viewed in isolation. State sovereignty has been an impediment to efforts to halt genocide as the GoS has maintained ultimate control over access to the country. This is a situation that is intensified by a general lack of will to intervene due to realpolitik interests of states that implicitly lie with supporting the GoS and not with halting genocide.

\section{Conclusion}

Writing in 1981, Kuper remarked that the Genocide Convention was a "dead letter." 146 Over thirty years and a number of genocides later, his comment remains largely accurate. The Convention was created in the aftermath of Second World War to mitigate the absolute nature of a fundamental principle of the nation-state system; namely, state sovereignty, which Lemkin argued could no longer allow states to act with impunity. With its moral obligation and unanimous promise to "liberate mankind" from the "odious scourge" of genocide it also attempts to address realpolitik decision making. In both endeavors it has been disappointing. Far from being a tool for the prevention and halting of genocide, it appears to have become more useful to those who wish to avoid action. ${ }^{147}$ At the time of writing, genocide is ongoing in Darfur and has been used to describe violence in the CAR, as well as Syria and Iraq.

The analysis of this article has shown that the Genocide Convention certainly has its flaws and is an impediment to the prevention and halting of genocide in terms of its failure to clarify what the obligation to prevent entails, including what actions might be required and legitimate, its definitional ambiguities which cause debilitating debates over whether a situation is in fact genocide, and its punitive focus which draws attention away from prevention and intervention. ${ }^{148}$ However, its utility is essentially bound up with the concept of state sovereignty and problems related to levels of political interest in a complex, intersecting relationship. State sovereignty can obstruct the flow of information crucial to a genocide determination, brings up tricky questions over what and when preventive action is legitimate, and more importantly, how the UN should balance its often contradictory roles of, on the one hand, a defender of sovereignty and, on the other, an organization committed to the prevention of genocide. Underlying both the Convention's deficiencies and state sovereignty are the problems of levels of political interests. A low level of political interest or a high level of differing realpolitik interests can both be disastrous for prevention and intervention as politicians manipulate state sovereignty and the deficiencies of the Genocide Convention in order to ensure that their national interests are met which, based on the three cases discussed, usually includes avoiding action in the face of genocide.

Understanding the relationship between the factors that contributed to past failures to prevent genocide is crucial as the twenty-first century is rapidly becoming another "century of genocide." Though steps have been taken to improve the possibility of prevention outside of the problematic framework of the Genocide Convention through the creation of the OSAPG and R2P, these initiatives, like the Convention, are similarly bound up with state sovereignty and political interest which will ultimately impact their effectiveness. The current crisis in the CAR is already suggestive of this. In a joint statement in October 2013, the SAPG, Adama Dieng, and the Special Adviser on the Responsibility to Protect, Jennifer Welsh, invoked R2P in relation to the CAR. ${ }^{149}$ Echoing Darfur, in December 2013, the Security Council issued Resolution 2127, which called for the creation of a commission of inquiry to investigate human rights violations in the CAR, and for the creation of the International Support Mission for the Central African Republic (MISCA) formed from African soldiers that would bolster French troops already on the ground. ${ }^{150}$ In April 2014, the Security Council voted to send a UN peacekeeping force which would increase the joint force to 12,000 , although only 1,800 troops had arrived in September with the remainder not expected to arrive until early 2015. ${ }^{151}$ In June 2014, the COI for the CAR, issued a report, which, echoing the Darfur Report, stated that "it was too early to speak of genocide or ethnic cleansing" though did acknowledge that crimes against humanity and war crimes had taken place. ${ }^{152}$ This finding was in spite of concluding that "widespread attacks were directed against the civilian population... driven, at least in part, by a desire to kill as many Muslims as possible... and efforts were made to kill even those who were seeking to flee the country." 153 The report has been utilized in the media more as a confirmation of the absence of genocide, rather than as a confirmation of the urgency 
to act. ${ }^{154}$ As such, the title of a Huffington Post article, "A Country is on the Brink of Genocide and Very Few Know About It," accurately summarizes the present situation. ${ }^{155}$ In a political context in which a number of crises have been described in terms of genocide, including Syria and Iraq, like Rwanda, the CAR is a low priority. Thus, over a year later, very little progress has been made in halting its escalation and although condemning a resurgence of violence in January 2015, UN investigators are now calling for the establishment of an international tribunal. ${ }^{156}$ Only time will tell whether the international community can rise to the challenge and make "never again" a reality in respect to the CAR.

\section{Acknowlegments}

I would like to thank Aristotle Kallis for his invaluable insights, support and guidance in writing this article. This work was supported by the Economic and Social Research Council [ES/ J500094/1]. I would also like to thank the anonymous reviewers and editors for their constructive comments and feedback.

\section{Endnotes}

1 Convention on the Prevention and Punishment of the Crime of Genocide (9 December 1948), United Nations Treaty Series, Vol. 78, 277.

2 General Assembly, 179th Plenary Meeting (9 December 1948), UN Doc. A/C.6/179, 824.

3 General Assembly, 178th Plenary Meeting (9 December 1948), UN Doc. A/C.6/178, 822.

4 179th Plenary Meeting, 825.

5 Of course its true impact as a preventive deterrent is problematic, if not impossible, to qualify since genocide itself is usually difficult to identify prior to the outbreak of violence. In my discussion, I focus on analyzing cases where violence had broken out and where genocide was either suspected or has since been identified as having occurred. Thus, my use of "prevention" in this article should be taken to mean the prevention of the escalation of violence or the halting of genocide rather than as a pre-emptive, deterrent type response.

6 Matthew Lippman, "Road Map to the 1948 Convention on the Prevention and Punishment of the Crime of Genocide," Journal of Genocide Research 4, 2 (2002), 191.

7 W. Michael Reisman, "Acting Before Victims Become Victims: Preventing and Arresting Mass Murder," Case Western Reserve Journal of International Law, 40 (2007-2008), 63; Samantha Power, A Problem from Hell: America and the Age of Genocide (London: Flamingo, 2003), 140-5.

8 Linda R. Melvern, A People Betrayed: The Role of the West in Rwanda's Genocide (London: Zed Books, 2000$), 74$.

9 Adam Jones, Genocide: A Comprehensive Introduction, $2^{\text {nd }}$ ed. (London: Routledge, 2011), 450.

10 David Smith, "Unspeakable Horrors in a Country on the Verge of Genocide," The Guardian (22 November 2013).

11 “New CAR PM says Ending Atrocities is Priority," Al Jazeera (26 January 2014).

12 "Christian Threats Force Muslim Convoy to Turn Back in CAR Exodus," The Guardian (14 February 2014).

13 Quoted in Alex Duvall Smith, “Central African Republic: 'Seeds of Genocide' Being Sown, Warns UN," The Guardian (16 January 2014).

14 Quoted in Josie Ensor, "Ban Ki-moon Warns of Rwandan Genocide Repeat in Central African Republic," The Telegraph (April 2014).

15 “Central Africa Republic Rebel Chief Rejects Ceasefire,” BBC News (25 July 2014); see http://www.amnesty. org/en/region/central-african-republic for Amnesty International's news and publications on the situation (Accessed January 2015); see also Report of the Secretary-General on the Situation in the Central African Republic (28 November 2014), UN Doc. S/2014/857, 1-3.

16 Alex Alvarez, "The Prevention and Intervention of Genocide During the Cold War Years," The Prevention and Intervention of Genocide, Genocide: A Critical Bibliographical Review, Volume 6, ed. Samuel Totten (New Brunswick and London: Transaction Publishers, 2008), 10-1.

17 Power, Problem from Hell, 87.

18 For an excellent overview of the ruthless regime and its aims, see Ben Kiernan, The Pol Pot Regime: Race, Power, and Genocide in Cambodia Under the Khmer Rouge, 1975-79, $3^{\text {rd }}$ ed. (New Haven, CT and London: Yale University Press, 2008). 
19 For further information on the complexities of the border war between Democratic Kampuchea and Vietnam see Elizabeth Becker, When the War Was Over: Cambodia and the Khmer Rouge Revolution (New York: Public Affairs, 1998), 291-3.

20 Security Council, 2108th Meeting (11 January 1979), UN Doc. S/PV.2108(OR), 11-3.

21 Ibid., 7-9.

22 See Becker, War Was Over, 340-5, for more on this.

23 Ibid., 294, 395.

24 2108th Meeting, 17.

25 Ibid., 10.

26 Becker, War Was Over, 364-9.

27 As quoted in Ben Kiernan, "Documentation Delayed, Justice Denied: The Historiography of the Cambodian Genocide," The Historiography of Genocide ed. Dan Stone (Basingstoke: Palgrave Macmillan, 2010), 469.

28 Power, Problem from Hell, 154.

29 2108th Meeting, 15.

30 Security Council, 2110th Meeting (13 January 1979), UN Doc. S/PV.2110(OR), 7-8.

31 Power, Problem from Hell, 154.

32 Reisman, "Acting before," 63.

33 Jackson Nyamuya Maogoto, "The Concept of State Sovereignty and the Development of International Law," The Genocide Studies Reader, ed. Samuel Totten and Paul R. Bartrop (New York: Routledge, 2009), 290-1; see also Paul R. Bartrop, “Political Realism, Sovereignty and Intervention: Is Genocide Prevention Really Possible in a World of Nation State?" Genocide and Mass Atrocities in Asia: Legacies and Prevention, ed. Deborah Mayerson and Annie Pohlman (London: Routledge, 2013), 119-35 for discussion of the development and evolution of state sovereignty.

34 Power, Problem from Hell, 19.

35 Charter of the United Nations (26 June 1945), Chapter I, Article 2(7).

36 Bruce Cronin, "The Tension between Sovereignty and Intervention in the Prevention of Genocide," Prevention and Intervention, ed. Totten, 148-9.

37 2110th Meeting, 3.

38 Commission on Human Rights Report (hereafter CHR Report), Thirty-fifth Session (9 March 1979), UN Doc. E/ CN.4/SR.1510, 7 .

39 General Assembly Resolution 34/22 (14 November 1979), UN Doc. A/RES/34/22.

40 Leo Kuper, Genocide: Its Political Use in the Twentieth Century (New Haven, CT: Yale University Press, 1982), 182.

41 Bartrop, "Political Realism," 120.

42 Elizabeth Becker was one of these journalists. See her book, War Was Over for details of the trip.

43 Kiernan, “Documentation Delayed," 469-70.

44 Gregory H. Stanton, "The Cambodian Genocide and International Law," Paper presented at Yale Law School (February, 1992).

45 Commission on Human Rights, Thirty-first Session (14 August 1978), UN Doc. E/CN.4/Sub.2/414/Add.1, 2.

46 Ibid., UN Doc. E/CN/Sub.2/414, 2.

47 Telegram from the Minister of Foreign Affairs of Democratic Kampuchea, addressed to the Sub-Commission on Prevention of Discrimination and Protection of Minorities (16 September 1978), UN Doc. E/CN.4/Sub.2/414. Add.9

48 Becker, War was Over, 439.

49 2110th Meeting, 3.

50 CHR Report, 7.

51 Bartrop, “Political Realism," 120.

52 Michael Barnett, Eyewitness to a Genocide: The United Nations and Rwanda (Ithaca, NY and London: Cornell University Press, 2002), 25-6.

53 M. Cherif Bassiouni, "Realpolitik," Genocide Studies Reader, ed. Totten and Bartrop, 288. 
54 Helen Fein, "The Three P's of Genocide Prevention: With Application to a Genocide Foretold-Rwanda," Genocide Studies Reader, ed. Totten and Bartrop, 332; Scott Straus, "The Historiography of the Rwandan Genocide," Historiography of Genocide, ed. Stone, 533.

55 Jared Cohen, One Hundred Days of Silence: America and the Rwanda Genocide (Plymouth, UK: Rowman and Littlefield Publishers Inc, 2007), 10-11.

56 Frank Chalk, Roméo Dallaire, Kyle Matthews, Carla Barquiero, and Simon Doyle, Mobilizing the Will to Intervene: Leadership to Prevent Mass Atrocities (Montreal: McGill-Queen's University Press, 2010), 23.

57 Barnett, Eyewitness, 52.

58 Chalk et al., Mobilizing, 23.

59 See Barnett, Eyewitness, 49-73, for more detailed overview of the historical background of the genocide.

60 Bacre Waly Ndiaye, Report of the Special Rapporteur on Extrajudicial, Summary or Arbitrary Executions (11 August 1993), UN Doc. E/CN.4/1994/7/Add.1. 23.

61 Alison Des Forges, "Leave None to Tell the Story: Genocide in Rwanda," Human Rights Watch (1999), 4-5; Cohen, One Hundred Days, 31-7.

62 Des Forges, “Leave None," 119.

63 Boutros Boutros-Ghali, "Introduction," The United Nations and Rwanda, 1993-1996, United Nations Blue Book Series, Vol. 10 (New York: Dept. of Public Information, United Nations, 1996), 37.

64 Cohen, One Hundred Days; Linda Melvern, "The UK Government and the 1994 Genocide in Rwanda," Genocide Studies and Prevention 2,3 (2007), 249-57. http://dx.doi.org/10.3138/gsp.2.3.249

65 Cohen, One Hundred Days, 59-64.

66 Barnett, Eyewitness, 34-7.

67 For a more detailed analysis of the impact of Somalia on US policy making see Cohen, One Hundred Days, 49-53.

68 See Barnett, Eyewitness, 39-48, for more information on the impact of Somalia on the UN.

69 Chalk et al, Mobilizing, 5.

70 Melvern, “UK Government,” 256.

71 Melvern, People Betrayed, 141.

72 Security Council Resolution 912 (21 April 1994), UN Doc. S/RES/912; Special Report of the Secretary-General on the United Nations Assistance Mission for Rwanda (20 April 1994), UN Doc. S/1994/470. Para. 15-8.

73 Boutros-Ghali, "Introduction," 46; Report of the Secretary-General on the Situation in Rwanda (13 May 1994), UN Doc. S/1994/565. Para. 16; Straus, "Rwandan Genocide," 533.

74 Security Council Resolution 918 (17 May 1994), UN Doc. S/RES/918.

75 Des Forges, "Leave None," 24. For further detail of the diplomatic shuffling that took place see Barnett, Eyewitness, 130-52;

76 Gregory H. Stanton, “The Rwandan Genocide: Why Early Warning Failed,” Journal of African Conflicts and Peace Studies 1,2 (September, 2009), 15-7. http://dx.doi.org/10.5038/2325-484X.1.2.1

77 Cohen, One Hundred Days, 132-40; Douglas Jehl, “Officials Told to Avoid Calling Rwanda Killings 'Genocide',' New York Times (10 June 1994).

78 Stanton, “Why Early Warning Failed," 14; Power, Problem from Hell, 355-6.

79 Barnett, Eyewitness, 101-2.

80 Melvern, People Betrayed, 180.

81 Power, Problem from Hell, 361.

82 Melvern, People Betrayed, 180.

83 Barnett, Eyewitness, 132.

84 Ibid.,135-6; Power, Problem from Hell, 364.

85 Fein, “The Three P's of Genocide," 330.

86 Stanton, "Why Early Warning Failed," 19.

87 Christine Shelly as quoted in Power, Problem from Hell, 359-60.

88 Chalk et al, Mobilizing, 37. 
89 The Responsibility to Protect: Report of the International Commission on Intervention and State Sovereignty (December, 2001). Paras. 2.14 \& 2.30-2.31.

90 For further information and access to relevant R2P documents see http://www.responsibilitytoprotect.org/ index.php/about-R2P/the-un-and-R2P. (Accessed June 2014); see also Bartrop, "Political Realism," 129-33 for further discussion.

91 Letter dated 12 July 2004 from the Secretary-General addressed to the President of the Security Council (12 July 2004), UN Doc. S/2004/567, 2.

92 Juan Méndez, "The United Nations and the Prevention of Genocide," The Criminal Law of Genocide: International, Comparative and Contextual Aspects, ed. Ralph Henham and Paul Behrens (Aldershot: Ashgate, 2007), 228.

93 See OSAPG, "Analysis Framework" and "Country Situations" available at http://www.un.org/en/ preventgenocide/adviser/ (Accessed June 2014).

94 Scott Straus, “Darfur and the Genocide Debate," Foreign Affairs 84, 2 (January/February, 2005), 123-4. http://dx.doi.org/10.2307/20034212

95 Michael Clough, “Darfur: Whose Responsibility to Protect?” Human Rights Watch (2005), 1.

96 Report of the International Commission of Inquiry on Darfur to the United Nations Secretary-General, (hereinafter Darfur Report) (25 January 2005), 3.

97 For a more in-depth overview of these origins see Gérard Prunier, Darfur: The Ambiguous Genocide (London: Hurst and Company, 2005)

98 Scott Straus, "Rwanda and Darfur: A Comparative Analysis," Genocide Studies and Prevention 1, 1 (2006), 44-5. http://dx.doi.org/10.3138/V503-3258-VW87-324T

99 René Lemarchand, “Unsimplifying Darfur," Genocide Studies and Prevention 1, 1 (2006), 5; Straus, "Rwanda and Darfur," 45.-

100 Lemarchand, "Unsimplifying Darfur," 5-9 for further information regarding the regional dimension of the violence.

101 Straus, “Rwanda and Darfur,” 45-6.

102 Lemarchand, "Unsimplifying Darfur," 6.

103 Prunier, Darfur, 125-6.

104 Darren Brunk, “Dissecting Darfur: anatomy of a genocide debate," International Relations 22, 1 (2008), 2930; Hugo Slim, "Dithering over Darfur? A Preliminary Review of the International Response," International Affairs 80, 5 (2004), 813-5.

105 Brunk, “Dissecting Darfur," 33-4.

106 Department of State, Documenting Atrocities in Darfur (September 2004), available at http://2001-2009.state. gov/g/drl/rls/36028.htm. (Accessed June 2014).

107 Colin Powell, "The crisis in Darfur," Testimony before the Senate Foreign Relations Committee (9 September 2004), available at http://2001-2009.state.gov/secretary/former/powell/remarks/36042.htm. (Accessed June 2014).

108 Security Council Resolution 1564 (18 September 2004), UN Doc. S/RES/1564. Para 12.

109 Darfur Report, 2-4.

110 It has been suggested that the methodology of the COI was not as rigorous as the US investigation, see footnote 50, in Samuel Totten, “The US Investigation into the Darfur Crisis and the US Government's Determination of Genocide," Genocide Studies and Prevention, 1, 1 (Jul., 2006), 76-77; see also Samuel Totten, “The UN International Commission of Inquiry on Darfur: New and Disturbing Findings," Genocide Studies and Prevention, 4, 3 (2009), 354-78.

111 Documenting Atrocities; Darfur Report, 129.

112 Ibid.

113 Darfur Report, Para. 513; for further discussion of the COI's findings see Totten, “The UN," 355-6, 367-71.

114 Beth Van Schaack, "Darfur and the Rhetoric of Genocide," Whittier Law Review 26 (2005), 1126-35.

115 Totten, “The UN," 356-7.

116 Frank Chalk and Kurt Jonassohn, The Historiography and Sociology of Genocide: Analyses and Case Studies (New Haven, CT: Yale University Press, 1990), 11-2.

117 Ibid., 25. 
118 Samuel Totten, “The Darfur Genocide," Genocide Studies Reader, ed. Totten and Bartrop, 196.

119 Documenting Atrocities.

120 Darfur Report, Para 508.

121 Lemarchand, “Unsimplifying Darfur," 4-5.

122 Darfur Report, Para. 510-2.

123 Van Schaack, "Rhetoric," 1115-35 for further discussion.

124 Straus, “Darfur," 133.

125 Van Schaack, "Rhetoric," 1141.

126 Jerry Fowler, "A New Chapter of Irony: The Legal Implications of the Darfur Genocide Determination," Genocide Studies and Prevention 1, 1 (2006), 36.

127 Jones, Genocide, 540-1.

128 Quoted in “Bush honors victims of Rwanda genocide," NBC News (19 February 2008).

129 David Luban, "Calling Genocide by its Rightful Name: Lemkin's Word, Darfur, and the UN Report," Chicago Journal of International Law 7, 1 (2006), 304-6.

130 Ibid., 305-6.

131 Akshaya Kumar \& Jacinth Planer, "The Forgotten Genocidal War in Darfur Revealed in New Satellite Photos," The Daily Beast (March 24, 2014).

132 Powell, "Crisis in Darfur".

133 Eric Reeves, "Secretary of State Colin Powell's Genocide Determination: What it Does, and Doesn't, Mean for Darfur" (10 September 2004).

134 Darfur Report, Para. 569-570.

135 Edward S. Herman and David Peterson, The Politics of Genocide (New York: Monthly Review Press, 2010), 104.

136 “Warrant Issued for Sudan's Leader," BBC News (4 March 2009).

137 “Sudan: ICC Warrant for Al-Bashir on Genocide," Human Rights Watch (July 2010).

138 “Defiant Sudan Sets Deadline for Darfur Peacekeeping Exit," Taipei Times (5 September 2006).

139 “Sudan: UN resolution for Darfur - An important but insufficient first step towards protecting civilians," Refugees International (2 August 2007).

140 Amnesty International, Obstruction and Delay: Peacekeepers Needed in Darfur Now (22 October 2007).

141 Tajeldin Abdhalla, Assadig Mustafa Zakira Musa, Katy Glassborow and Simon Jennings, "Khartoum Under Fire Over IDP Camp Conditions," Global Voices Africa (19 November 2010).

142 "Sudan Becomes US Ally in 'War on Terror'," The Guardian (30 April 2005).

143 Eric A. Heinze, “The Rhetoric of Genocide in U.S. Foreign Policy: Rwanda and Darfur Compared," Political Science Quarterly 122, 1 (2007), 376-8. http://dx.doi.org/10.1002/j.1538-165x.2007.tb00602.x

144 Eric Reeves, “Partners in Genocide: A Comprehensive Guide to China's Role in Darfur" (19 December 2007).

145 “Darfur: New Weapons from China and Russia Fuelling Conflict,” Amnesty International (8 February 2012).

146 Kuper, Genocide, 175.

147 Jared Cohen quoted in Chalk et al, Mobilizing, 37.

148 See Samuel Totten, "The Wording and Interpretation of the UN Convention on the Prevention and Punishment of the Crime of Genocide: An Ongoing Impediment," Impediments, ed. Totten, 77-111, for further discussion.

149 Statement by Mr. Adama Dieng, United Nations Special Adviser on the Prevention of Genocide, and Ms. Jennifer Welsh, United Nations Special Adviser on the Responsibility to Protect, on the situation in the Central African Republic (01 October 2013).

150 Security Council Resolution 2127 (05 December 2013).

151 “UN Peacekeepers to take over CAR Mission,” Al Jazeera (16 September 2014).

152 Quoted in “Central African Republic crisis: War crimes committed - UN," BBC News (5 June 2014).

153 Final Report of the International Commission of Inquiry on the Central African Republic (22 December 2014), UN Doc. S/2014/928, 94. 
154 For example, see "UN report sees no genocide in C. African Republic," The Washington Post (5 June 2014).

155 Eline Gordts, "A Country is on the Brink of Genocide and Very Few Know About It," The Huffington Post (6 May 2014).

156 “UN says International Court needed for CAR War Crimes,” Al Jazeera (22 January 2015). 